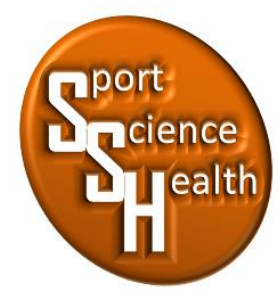

ISSN 2715-3886

\title{
Hubungan Tren Bersepeda dimasa Pandemi Covid-19 dengan Imunitas Tubuh Lansia
}

\author{
Ema Novita Deniati ${ }^{1 *}$, Annisaa ${ }^{2}$ \\ 1,2Jurusan Ilmu Kesehatan Masyarakat, Fakultas IImu Keolahragaan, Universitas Negeri Malang, \\ Jalan Semarang No 5, Malang, Jawa Timur, 65145, Indonesia \\ *Penulis koresponden: ema.deniati.fik@um.ac.id, 081250155155
}

Artikel diterima: 14 Februari 2021; direvisi: 15 Maret 2021; disetujui: 20 Maret 2021

\begin{abstract}
The number of positive incidents, mortality and mortality due to Covid-19 is getting higher. In 2020, around $76.7 \%$ of elderly people died because of Covid- 19 from the total number of patients who died due to Covid- 19 . This increasing number is not in line with the activity of cycling trends that were rife during the Covid-19 pandemic. So that there is a mismatch with the principles of health sports, namely sports to improve the health status of sports players. Therefore, this study is important to do to determine the relationship between cycling trends during the pandemic and increased immunity, especially for the elderly. The research method used is a literature review of various research articles that have been published in various journals indexed by Google Scholar, Research Gate, Scopus, and PubMed. The articles reviewed were articles related to cycling and the immunity of the elderly during the Covid-19 pandemic. Based on the analysis of the articles that have been done, there is a relationship between cycling and the immunity of the elderly. However, the SARS CoV-2 virus can infect healthy people without symptoms which then spreads to the elderly and causes high cases of mortality in the elderly. So that it requires active participation by all parties to prevent the spread of Covid-19 and improve the immune system in the midst of a pandemic with cycling.
\end{abstract}

Keyword: cycling; pandemic; immunity; elderly; covid-19

\begin{abstract}
Abstrak: Angka kejadian positif, mordibitas, dan mortalitas akibat Covid-19 semakin tinggi. Pada tahun 2020 terdapat sekitar 76,7\% lansia yang meninggal karena Covid-19 dari total keseluruhan pasien meninggal akibat Covid-19. Angka yang semakin naik tersebut tidak sejalan dengan aktifitas tren bersepeda yang marak diminati saat pandemi Covid-19. Sehingga terdapat ketidaksesuaian dengan prinsip olahraga kesehatan yaitu olahraga untuk meningkatkan derajat kesehatan bagi pelaku olahraga. Oleh karena itu, penelitian ini penting dilakukan untuk mengetahui adanya hubungan antara tren bersepeda dimasa pandemi terhadap peningkatan imunitas tubuh khususnya bagi lansia. Metode penelitian yang digunakan yaitu review literatur dari berbagai artikel penelitian yang telah terpublikasi dalam berbagai jurnal yang terindeks Google Cendekia, Research Gate, Scopus, dan PubMed. Artikel yang direview yaitu artikel yang berhubungan dengan olahraga bersepeda dan imunitas tubuh lansia dimasa pandemi Covid-19. Berdasarkan analisis artikel yang telah dilakukan, terdapat hubungan antara olahraga bersepeda dengan imunitas tubuh lansia. Namun, virus SARS CoV-2 dapat menjangkit pada orang sehat tanpa gejala yang kemudian menyebar ke lansia dan menyebabkan tingginya kasus mortalitas pada lansia. Sehingga diperlukan partisipasi aktif oleh semua pihak untuk mencegah penyebaran Covid-19 dan meningkatkan sistem imunitas tubuh di tengah pandemi dengan olahraga bersepeda.
\end{abstract}

Kata kunci: bersepeda; pandemi; imunitas; lansia; covid-19 


\section{PENDAHULUAN}

Virus corona (Covid-19) berasal dari Wuhan, China yang ditemukan pertama kali pada bulan Desember 2019. Virus corona atau bisa disebut dengan severe acute repiratory syndrome coronavirus (SARS-CoV-2) merupakan virus yang menyerang sistem pernapasan dan virus ini masih satu keluarga dengan virus sindrom pernapasan akut (SARS) (Zhou et al., 2020). Awalnya, virus ini merupakan epidemi yang berubah menjadi pandemi antara bulan Januari-April 2020 di China dan menyebar ke seluruh dunia hingga saat ini (Dryhurst et al., 2020). World Health Organization (WHO) telah mengkategorikan Covid-19 ke dalam pandemi pada tanggal 11 Maret 2020 (Gharizadeh et al., 2020). Virus corona diperkirakan berasal dari pasar hewan dan makanan laut di kota Wuhan sehingga dapat terjadi penularan dari hewan ke manusia. Selain itu, terdapat informasi lain bahwa virus corona berasal dari kelelawar dan ular (Santoso, 2020). Namun, sampai saat ini belum dipastikan darimana asal mula virus Covid-19. Peningkatan penyebaran virus Covid-19 tergolong signifikan karena virus ini dapat menyebar melalui melalui udara dan kontak langsung dengan penderita (Shereen et al., 2020).

Menurut penelitian dari University of Texas di Austin, Amerika Serikat, yang dipublikasikan dalami jurnal Emerging Infectious Disease, rantai penularan corona berlangsung kurang dari satu minggu dan lebih dari 10 persen pasien tertular oleh orang yang telah terinfeksi virus tetapi belum menunjukkan gejala atau disebut dengan orang tanpa gejala (OTG) (The University of Texas at Austin, 2020). Pada tanggal 30 Januari 2020, WHO menetapkan Covid-19 sebagai Public Health Emergency of International Concern (PHEIC) (Suni, 2020). Berdasarkan data dari (Johns Hopkins University CSSE, 2020) per 12 Februari 2020,sebanyak 1.114 orang meninggal karena terpapar penyakit Covid-19, sedangkan sebanyak 4.698 orang sembuh. Menurut data dari worldmeters.info, Amerika Serikat masih menjadi negara yang mempunyai kasus tertinggi di dunia yakni 20.216.991 dan 350.778 meninggal dunia. Total kasus positif Covid-19 di dunia hingga Kamis, 31 Desember 2020 telah mencapai 83.060.276 dengan 1.812.046 meninggal dunia.

Di Indonesia, pada tanggal 2 Maret 2020 dua orang warga Indonesia untuk pertama kalinya diumumkan menjadi pasien positif Covid-19. Namun, pakar Epidemiologi Universitas Indonesia, Pandu Riono menyatakan bahwa virus corona mulai masuk ke Indonesia sudah sejak awal Januari (CNN Indonesia, 2020). Virus corona bisa menyebar dalam jarak yang dekat. Penyebaran virus ini hampir sama dengan penyakit flu, yaitu melalui droplet atau percikan air ludah orang seseorang yang terinfeksi virus (Shereen et al., 2020). Menurut WHO, lontaran droplet bisa mencapai 1 meter sehingga jarak yang direkomendasikan antara satu orang dengan orang lain sepanjang 2 meter dengan waktu kurang dari 45 menit agar resiko tertular rendah (Kemenkes RI, 2020). Seseorang yang terinfeksi virus corona memiliki gejala umum seperti demam, batuk, dan sesak napas (Aronna et al., 2021). Berdasarkan data Covid-19 sejak pertama kali ditemukan di Indonesia hingga 31 Desember 2020, jumlah positif Covid-19 sebanyak 743.198 pasien, sebanyak 611.097 pasien sembuh, dan sebanyak 22.138 pasien meninggal dunia akibat Covid-19 (Verdiana, 2020).

Kasus kematian akibat Covid-19 banyak terjadi pada seseorang dengan penyakit penyerta dan pada seseorang lanjut usia (Papadopoulos et al., 2021). Menurut World Health Organization (WHO), lanjut usia (lansia) adalah kelompok penduduk yang berumur 60 tahun atau lebih. Secara global pada tahun 2013 proporsi dari populasi penduduk berusia lebih dari 60 tahun adalah $11,7 \%$ dari total populasi dunia dan diperkirakan jumlah tersebut akan terus meningkat seiring dengan peningkatan usia harapan hidup. Berdasarkan data WHO menunjukan pada tahun 2000 usia harapan hidup orang di dunia adalah 66 tahun, pada tahun 2012 naik menjadi 70 tahun dan pada tahun 2013 menjadi 71 tahun (WHO, 2013). Sejalan dengan hal tersebut, jumlah proporsi lansia di Indonesia juga bertambah setiap tahunnya. Berdasarkan data WHO pada tahun 2015 dalam Sagitta,2017 menunjukkan lansia berjumlah 7,49\% dari total populasi pada tahun 2009, di tahun 2011 menjadi 7,69\% dan pada tahun 2013 didapatkan proporsi lansia sebesar 8,1\% dari total populasi. Berdasarkan data proyeksi penduduk, diperkirakan tahun 2017 terdapat 23,66 juta jiwa penduduk lansia di Indonesia (9,03\%) dan diprediksi jumlah penduduk lansia tahun 2020 (27,08 juta), tahun 2025 (33,69 juta), tahun 2030 (40,95 juta) dan tahun 2035 (48,19 juta) (Kementerian Kesehatan RI, 2017). Dari peningkatan jumlah lansia yang semakin banyak di tiap tahunnya diiringi juga dengan permasalahan kesehatan pada populasi lansia antara lain sebanyak $63.5 \%$ lansia menderita hipertensi, $5.7 \%$ lansia dengan diabetes mellitus, $4.5 \%$ lansia dengan penyakit jantung, $4.4 \%$ lansia dengan stroke, $0.8 \%$ lansia dengan gangguan ginjal, dan $0.4 \%$ lansia menderita kanker (Kementerian Kesehatan RI Badan Penelitian dan Pengembangan, 2018). 
Pada era pandemi saat ini, kelompok lansia merupakan kelompok yang paling berisiko mengalami kesakitan atau morbiditas dan mortalitas akibat penyakit Covid-19 (Mueller et al., 2020). Data mortalitas akibat Covid19 di beberapa negara lain menunjukkan peningkatan seiring dengan meningkatnya usia, seperti di Tiongkok jumlah kematian pada populasi usia 60-69 tahun sebesar 3.6\%, pada usia 70-79 tahun sebesar 8\% dan pada usia lebih dari 80 tahun sebanyak $14.8 \%$. Hal ini dikarenakan pasien lansia (geriatric) umumnya memiliki berbagai komorbiditas, seperti penyakit kardiovaskular, penyakit kencing manis, penyakit pernapasan kronik, hipertensi dan lain-lain (Rydyznski Moderbacher et al., 2020). Hal ini senada dengan Indonesia, dimana menurut data Kementerian Kesehatan tahun 2020 menyatakan bahwa angka mortalitasnya meningkat seiring dengan meningkatnya usia yaitu pada populasi usia 45-54 tahun adalah 8\%, 55-64 tahun 14\% dan 65 tahun ke atas $22 \%$ (Yurianto, 2020). Untuk itu pencegahan penularan melalui upaya promotif dan preventif kepada kelompok lansia sangat penting dilakukan, baik di tingkat keluarga, masyarakat dan fasilitas kesehatan.

Virus corona secara umum menyerang sistem kekebalan tubuh khususnya pada sistem pernapasan manusia. Imunitas atau sistem imun merupakan sistem pertahanan tubuh manusia untuk melawan dan menghancurkan patogen yang masuk ke dalam tubuh karena sistem imunitas tubuh memiliki kemampuan untuk menanggapi sinyal lingkungan dan menerima berbagai macam gangguan fungsional lainnya (Buck et al., 2017). Imunitas tubuh semakin menurun seiring dengan semakin bertambahnya usia sebagai akibat dari proses penuaan (Wilk et al., 2020). Dengan menurunnya sistem imun pada lansia dan adanya penyakit penyerta mengakibatkan lansia mudah terserang berbagai penyakit, termasuk Covid-19 yang disebabkan oleh virus Sars-Cov-2 (Rydyznski Moderbacher et al., 2020). Sistem imunitas tubuh dapat ditingkatkan dan dikuatkan melalui olahraga teratur setiap minggu (S, 2017). Olaharaga yang banyak diminati dan menjadi tren selama pandemi Covid-9 yaitu olahraga bersepeda. Berdasarkan data Institute for Transportation and Development Policy (ITDP), pengguna sepeda meningkat 10 kali lipat di Jakarta dibandingkan dengan tahun lalu. Pada Oktober 2019, ITDP melaporkan hanya ada 21 pengguna sepeda di Jakarta. Namun, per Juni 2020 lalu, pengguna sepeda mencapai angka 235 di Jakarta (Institute for Transportation and Development Policy, 2020). Olahraga bersepeda ini muncul sebagai akibat dari penerapan PSBB di Indonesia yang mana masyarakat merasa jenuh di dalam rumah kemudian melakukan aktivitas bersepeda di luar rumah sebagai salah satu cara untuk mengurangi kejenuhan, mencari udara segar dan bersih, ramah lingkungan, aman, serta dapat menjaga jarak antara pesepeda satu dengan pesepeda lainnya (Ika, 2020). Bersepeda merupakan kegiatan olahraga yang termasuk olahraga low impact yang dapat menjaga kebugaran tubuh. Kegiatan bersepeda dapat memberikan banyak manfaat bagi tubuh, diantaranya mampu meningkatkan kesehatan jantung, paru-paru, sistem peredaran darah, dapat mencegah obesitas, membakar lemak, dan meningkatkan energi atau kekuatan dalam tubuh (S, 2017).

Di masa pandemi dianjurkan untuk melakukan aktivitas sedang dengan tetap memperhatikan prinsip umum latihan fisik yaitu frequency, intensity, time, dan type karena resiko terpapar infeksi atau penyakit rendah. Intensitas sedang adalah ketika melakukan aktivitas fisik, seseorang masih dapat berbicara walaupun terengah-engah. Olahraga dapat dilakukan minimal 2-3 kali dalam seminggu dengan durasi minimal 30-45 menit. Bagi lansia yang melakukan olahraga bersepeda dapat dilakukan dengan intensitas sedang, antara 40$60 \%$ dari volume $\mathrm{O} 2$ maksimal sebanyak 2-3 kali dalam seminggu (Hadi, 2020). Dengan demikian, para lansia dapat melakukan bersepeda dengan nyaman guna meningkatkan imunitas sehingga dapat mencegah penularan virus Covid-19 melalui upaya promotif dan preventif. Upaya ini dinilai sangat penting dilakukan terhadap lansia baik di tingkat keluarga, masyarakat dan fasilitas kesehatan.

\section{METODE}

Review artikel ini menggunakan beberapa artikel dalam jurnal penelitian yang diterindeks banyak database ilmiah seperti Google Scholar, Research gate, PubMed, dan Scopus. Selain menggunakan artikel dalam jurnal penelitian, review artikel ini juga menggunakan referensi dari kementerian kesehatan dan publikasi ilmiah lainnya. Desain review artikel ini menggunakan beberapa tahap penyaringan atau screening. Pencarian dilakukan melalui media elentronik. Pencarian ini dilakukan untuk mengidentifikasi literatur yang relevan dengan paling sedikit satu dari kata kunci berikut : "pandemi","tren bersepeda", "imunitas", "lansia", "immunity during pandemic", "covid-19", "elderly people immunity", dan "elderly activity during pandemic". Semua artikel muncul dalam hasil pencarian dibaca terlebih dahulu bagian abstrak. Kemudian, artikel dibaca secara keseluruhan menghasilkan 18 referensi artikel penelitian, buku, dan publikasi ilmiah dalam bentuk essay. 
Ulasan dibatasi untuk artikel yang melaporkan penelitian penemuan asli dan dipublikasikan dari Januari 2012 sampai Februari 2021. Penelitian yang tidak membahas pola olahraga bagi lansia, olahraga bersepeda, imunitas tubuh lansia, dan lansia di masa pandemi dikecualikan untuk diulas.

\section{HASIL}

Berdasarkan data dari Satgas Covid-19 dalam laman covid19.go.id menyatakan bahwa terdapat 1.174.779 orang yang terkonfirmasi positif terinfeksi Covid-19 semenjak Maret hingga 9 Februari 2021. Untuk kelompok rentan seperti lansia terdapat sekitar $34,2 \%$ atau sekitar 112.502 orang lansia dengan usia 45 tahun ke atas. Menurut publikasi Badan Pusat Statistik mengenai Statistik Penduduk Lanjut Usia 2019, di Indonesia pada tahun 2019 terdapat $9,60 \%$ atau sekitar 25,64 juta orang lansia. Dari keseluruhan lansia tersebut, terdapat sebanyak 26,20\% lansia yang mengalami kesakitan atau menderita penyakit.

Jumlah kasus orang terkonfirmasi positif Covid-19 terus meningkat. Bahkan terdapat sekitar $80,0 \%$ atau 25.581 orang lansia yang meninggal dari total keseluruhan 31.976 orang meninggal karena Covid-19 dalam rentang waktu sekitar 11 bulan sejak kemunculan pertama kali di Indonesia (Satgas Covid-19, 2021). Hampir sebagian besar lansia yang meninggal telah mederita penyakit sebelumnya seperti hipertensi, diabetes mellitus, penyakit jantung, penyakit ginjal, penyakit paru obstruktif kronis, dan kanker. Berdasarkan data Riskesdas,2013 dalam (Pusat Data dan Informasi, 2016) menyatakan bahwa penyakit kronik degeneratif yang banyak diderita lansia yaitu hipertensi, artritis, stroke, penyakit paru ostruktif kronik, diabetes mellitus, kanker, penyakit jantung koroner, batu ginjal, gagal jantung, dan gagal ginjal. Sehingga kelompok rentan seperti lansia mulai mendapatkan perhatian khusus baik dalam segi upaya pencegahan maupun upaya penanggulangan penyakit. Dalam upaya pencegahannya, lebih difokuskan pada peningkatan daya tahan tubuh lansia melalui berbagai kegiatan atau aktivitas fisik.

Salah satu upaya untuk menjaga, mencegah, meningkatkan kesehatan dan kesegaran jasmani bagi lansia (lanjut usia) adalah dengan melakukan olahraga. Olahraga bagi lansia yang dilakukan secara terprogram akan mempunyai beberapa manfaat, diantaranya adalah untuk mempertahankan kesehatan, meningkatkan kekuatan otot jantung, meningkatkan sirkulasi darah dalam tubuh, menurunkan kadar lemak, menguatkan otot-otot tubuh, mengurangi stress dan ketegangan batin, meningkatkan sistem kekebalan tubuh (S, 2017). Olahraga teratur bermanfaat bagi sistem kekebalan tubuh (immunoglobulin A) serta dapat mengurangi risiko tertular infeksi saluran pernapasan. Immunoglobulin A merupakan antibodi utama yang terkandung dalam sekresi kekebalan mukosa sebagai salah satu garis pertahanan pertama ketika melawan patogen infeksi sehingga sangat penting untuk melakukan olahraga di tengah pandemic Covid-19 (Yousfi et al., 2020). Berolahraga mampu membantu meningkatkan sel darah putih dan antibody untuk melawan infeksi penyakit, mampu meningkatkan massa otot, kekuatan, dan ketahanan tubuh, serta mampu mencegah pembekuan darah yang terjadi pada beberapa orang yang tertular Covid-19 (Arshad et al., 2020).

Menurut Agus Pribadi,2015 mengungkapkan bahwa olahraga bersepeda bagi lansia merupakan salah satu jenis latihan fisik aerobik yang mampu mencegah obesitas, mengurangi depresi atau stress atau kecemasan selama masa pandemik, menyehatkan paru-paru, menyehatkan jantung, dam masih banyak manfaat lainnya. Latihan aerobik seperti bersepeda bagi lansia harus memenuhi kriteria FITT yaitu frekuensi, intensitas, time (waktu), dan tipe. Frekuensi 3 kali satu minggu, intensitas 60-70\% dari denyut nadi maksimal, time atau waktu sekitar 20-30 menit tiap latihan, serta tipe olahraganya menyenangkan dan mudah.

Menurut penelitian yang telah dilakukan oleh Aviana Gita Lara dan Atik Choirul Hidajah (2016) menunjukkan bahwa terdapat hubungan antara kebiasaan olahraga dengan kualitas hidup lansia penderita diabetes mellitus 2 di Puskesmas Wonokromo Surabaya. Penelitian dilakukan pada bulan Januari hingga Juni 2016 dengan responden sebanyak 195 orang yang berobet pada periode bulan Januari-Maret 2015 di puskesmas tersebut. Penelitian tersebut menunjukkan bahwa terdapat sekitar $37,5 \%$ atau 36 orang yang tidak berolahraga secara teratur serta sekitar $62,5 \%$ atau 60 orang yang berolahraga secara teratur. Lansia penderita diabetes mellitus tipe 2 merupakan lansia dengan intensitas olahraga 3-5 kali dalam seminggu atau sekitar 30 menit tiap hari. Olahraga yang sering dilakukan yaitu senam, jalan kaki, dan bersepeda.

Penelitian yang dilakukan oleh Mersilia Suliyusta dan Etty Rekawati (2016) mengenai hubungan aktivitas fisik dan kemampuan kognitif pada lansia dengan 104 responden lansia yang berusia lebih dari 60 tahun. Dari keseluruhan lansia tersebut, ternyata jumlah lansia yang memiliki aktivitas tinggi dan rendah berimbang yaitu 
sebesar $50 \%$. Hasilnya adalah sebanyak 57 responden memiliki fungsi kognitif yang masih normal. Ini terdiri dari 40 responden dengan aktivitas fisik tinggi dan 17 responden dengan aktivitas rendah. Sedangkan 47 responden mengalami penurunan fungsi kognitif dengan 12 responden berasal dari tingkat aktivitas fisik tinggi dan 35 responden berasal dari tingkat aktivitas fisik rendah. Selain itu, menurut hasil analisis bivariat yang telah dilakukan menunjukkan bahwa ada hubungan bermakna antara tingkat fisik dengan fungsi kognitif lansia yaitu dengan nilai $p=0,000$.

Sejalan dengan penelitian tersebut, penelitian dari Ihsan Kurniawan dan Sulaiman (2019) di Posyandu Lansia di Kelurahan Sudirejo I Kecamatan Medan Kotayang meneliti 45 responden dengan 18 responden tidak melakukan olahraga $(40,0 \%)$ dan sebanyak 27 responden melakukan olahraga $(60,0 \%)$. Hasilnya yaitu sebanyak 34 responden mengalami hipertensi ringan $(75,6 \%)$ dan 11 responden mengalami hipertensi berat $(24,4 \%)$. Hal ini mengartikan bahwa olahraga yang sifatnya aerobik dan teratur serta dilakukan dengan benar minimal 30 menit perhari mampu menjaga kestabilan tekanan darah agar tetap normal.

Berdasarkan penelitian yang dilakukan oleh Egas A. Da Costa Xavier, dkk (2017) menunjukkan bahwa terdapat hubungan antara aktivitas fisik dengan tekanan darah pada lansia. Penelitian oleh Xavier dkk dilakukan dengan pendekatan cross sectional dan teknik non problabling sampling dengan 30 orang responden yang memenuhi syarat di lima Posyandu Lansia Desa Banjarejo Kecamatan Ngantang Kabupaten Malang. Dari penelitian tersebut terlihat 21 orang yang berolahraga dengan aktivitas sedang dan sisanya sebanyak 9 orang melakukan olahraga ringan. Hasilnya sebanyak 5 orang responden yang terdiri dari 1 responden beraktivitas fisik rendah dan 4 responden beraktivitas fisik sedang mengalami prehipertensi atau tahap belum/tidak menderita hipertensi, sebanyak 17 orang responden yang terdiri dari 3 responden beraktivitas fisik rendah dan 14 responden beraktivitas fisik sedang mengalami hipertensi tingkat pertama atau hipertensi ringan, terakhir 8 orang responden yang terdiri dari 5 responden beraktivitas fisik rendah dan 3 responden beraktivitas fisik sedang mengalami hipertensi tingkat kedua atau hipertensi parah.

Berdasarkan penelitian yang dilakukan oleh Faisal Kusuma Hadi (2020) dengan 200 orang responden, frekuensi latihan dalam seminggu di bagi menjadi lima kategori yaitu tidak pernah terdiri dari 10 responden, sekali terdiri dari 20 responden, dua kali terdiri dari 30 responden, tiga kali terdiri dari 60 responden, serta lebih dari tiga kali terdiri dari 80 responden. Hasilnya yaitu diukur dari ketercapaian kategori FITT. Kategori frekuensi terbanyak yaitu frekuensi latihan lebih dari tiga kali seminggu mencapai $40 \%$ dari keseluruhan 200 responden. Kategori intensitas latihan terbanyak yaitu intensitas latihan ringan mencapai $51 \%$ dari keseluruhan 200 responden. Kategori tipe latihan terbanyak yaitu tipe latihan aerobik mencapai $60 \%$ dari keseluruhan 200 responden. Kategori waktu durasi latihan terbanyak yaitu dirasi latihan 31-45 menit mencapai $50 \%$ dari keseluruhan 200 responden.

Bersepeda memiliki banyak sekali manfaat seperti yang telah dipaparkan dalam paragraf sebelumnya. Sehingga bersepeda pada masa sekarang ini telah menjadi tren olahraga yang sedang melanda seluruh kalangan masyarakat di berbagai kota di Indonesia bahkan di dunia. Berdasarkan survei The Institute of Transportation and Development Policy (ITDP) telah terjadi peningkatan jumlah pengguna sepeda selama masa PSBB transisi di Jakarta. Survei ini dilakukan pada hari kerja pada pukul 06.30 sampai dengan 08.00 WIB selama masa PSBB transisi bulan Juni 2020. Hasil dari survey yang dilakukan oleh ITDP yaitu terjadi peningkatan sebesar $93 \%$ hingga $1000 \%$ atau 10 kali lipat jumlahnya (Institute for Transportation and Development Policy, 2020). Selain itu, berdasarkan berita yang dilansir dalam bisnisnews.id,2020 menyatakan bahwa fenomena pesepeda mewarnai tren olahraga di dunia. Di Inggris, pemesanan sepeda naik hingga 200\% atau yang biasanya 20-30 sepeda per minggu meningkat hingga 50 sepeda tiap hari. Di Amerika Serikat, pengguna sepeda meningkat hingga 150\%. Bahkan sekitar $85 \%$ penduduk Amerika Serikat beranggapan bahwa sepeda merupakan alat transportasi umum yang aman ketika menjaga jarak sosial (Setijowarno \& Yulianti, 2020). Tren olahraga bersepeda menyerang seluruh kalangan usia mulai dari anak-anak, dewasa hingga lansia. Tren bersepeda kini digemari lantaran banyak yang beranggapan bahwa bersepeda memungkinkan penggunanya untuk tidak berdekatan dengan orang lain (Ika, 2020). Anggapan tersebut sesuai dengan anjuran pemerintah tentang "Ingat Pesan Ibu 3M : Memakai masker, Menjaga jarak, dan Mencuci tangan". Oleh karena itu, bagi mereka yang mulai merasakan bosan dengan adanya peraturan pemerintah untuk stay at home memilih olahraga bersepeda sebagai sarana menyegarkan otak, berolahraga, serta bersosialisasi dengan tetangga. 


\section{PEMBAHASAN}

Tren olahraga bersepeda muncul sebagai dampak dari penerapan PSBB di Indonesia. Masyarakat yang semakin jenuh dengan berdiam diri di rumah saja, mulai mencari aktivitas olahraga di luar rumah untuk sekedar menghilangkan penat, mencari udara segar, bersosialisasi namun tetap menjaga jarak dan menghindari kerumunan. Menurut penelitian-penelitian yang telah dibahas sebelumnya, tren olahraga bersepeda sebagai salah satu olahraga aerobik di masa pandemi Covid-19 sekarang ini dapat menjadi upaya pencegahan bagi lansia agar terhindar dari virus Covid-19. Hal ini dikarenakan, olahraga bersepeda bagi lansia mampu meningkatkan sistem imunitas tubuh lansia. Bersepeda mampu membuat mereka senang dan bahagia sebab mereka melakukannya dengan senang hati, lebih rileks, bisa menikmati keadaan alam sekitar, serta minim terjadi cidera. Selain itu, olahraga bersepeda mampu menjaga kekuatan jantung bagi lansia, meningkatkan imunitas tubuh lansia, meningkatkan kesehatan mental lansia, mengurangi risiko terkena infeksi patogen, serta mengurangi polusi udara akibat kendaraan bermotor.

Dalam melakukan olahraga bersepeda bagi lansia sebaiknya tidak sendirian atau dapat dilakukan bersama pasangan, anak, atau cucu mereka yang sudah remaja. Jika lansia sudah merasakan jantungnya berdebardebar atau berdenyut hingga mencapai 140-160 denyut per menit maksimal (DNM = 220-umur), maka lansia harus beristirahat dan menghentikan aktifitas olahraga bersepeda mereka. Oleh sebab itu, jangan biarkan lansia berolahraga sepeda sendirian. American College of Sport Medicine (ACSM) dalam Prijo Sudibjo, 2014 merekomendasikan latihan olahraga bersepeda sebagai berikut: (1) sebaiknya dapat dilakukan setiap hari, tetapi 3-5 kali setiap minggu sudah cukup efektif; (2) dengan intensitas sedang, antara $40-60 \%$ dari volume O2 maksimal; (3) lebih dari 30 menit setiap latihan; serta (4) dapat dokombinasikan dengan latihan kekuatan/beban ringan. Selain itu, di masa pandemi seperti sekarang ini perlu untuk selalu menerapkan protokol kesehatan di segala lini kehidupan tidak terkecuali olahraga. Oleh karena itu, dalam melakukan olahraga bersepeda, sebaiknya tetap menjaga jarak dengan orang lain jika bertemu di jalan, tidak berhenti ditempat yang ramai atau berkerumun, membawa air minum sendiri untuk mencegah dehidrasi, melakukan pemanasan terlebih dahulu untuk menghindari cedera, membawa handsanitizer, serta memakai face shield supaya masih bisa bernafas secara teratur dan menghindari paparan virus Covid-19.

\section{KESIMPULAN}

Angka mortalitas lansia karena Covid-19 semakin meningkat jumlahnya. Sehingga diperlukan imunitas tubuh yang kuat untuk menghindari risiko terpapar Covid-19. Salah satu alternatif yang dapat diterapkan untuk meningkatkan imunitas tubuh lansia yaitu dengan berolahraga secara teratur. Melalui olahraga bersepeda yang telah menjadi tren selama masa pandemic Covid-19 diharapkan mampu memacu semangat para lansia untuk tetap berolahraga karena banyak yang melakukan olahraga tersebut serta dengan olahraga bersepeda mampu menghilangkan kejenuhan lansia ketika harus dirumah terus menerus. Selain itu, diharapkan adanya partisipasi dari berbagai pihak atau stakeholder untuk dapat mengajak dan memberdayakan lansia untuk olahraga bersepeda dengan tetap menerapkan protokol kesehatan Covid-19.

\section{DAFTAR PUSTAKA}

Aronna, M. S., Guglielmi, R., \& Moschen, L. M. (2021). A model for COVID-19 with isolation, quarantine and testing as control measures. Epidemics, 34, 100437. https://doi.org/10.1016/j.epidem.2021.100437

Arshad, M. S., Khan, U., Sadiq, A., Khalid, W., Hussain, M., Yasmeen, A., Asghar, Z., \& Rehana, H. (2020). Coronavirus disease (COVID-19) and immunity booster green foods: A mini review. Food Science and Nutrition, 8(8), 3971-3976. https://doi.org/10.1002/fsn3.1719
Badan
https://www.bps.go.id/publication/2019/12/20/ab17e75dbe630e05110ae53b/statistik-penduduk-lanjut- usia-2019.html

Buck, M. D., Sowell, R. T., Kaech, S. M., \& Pearce, E. L. (2017). Metabolic Instruction of Immunity. Cell, 169(4), 570-586. https://doi.org/10.1016/j.cell.2017.04.004

CNN Indonesia. (2020). UI Ungkap Kronologi Negara Abai Virus Corona Masuk RI Januari. 
https://www.cnnindonesia.com/teknologi/20200420160222-199-495344/ui-ungkap-kronologi-negaraabai-virus-corona-masuk-ri-januari

Dryhurst, S., Schneider, C. R., Kerr, J., Freeman, A. L. J., Recchia, G., van der Bles, A. M., Spiegelhalter, D., \& van der Linden, S. (2020). Risk perceptions of COVID-19 around the world. Journal of Risk Research, 23(7-8), 994-1006. https://doi.org/10.1080/13669877.2020.1758193

Gharizadeh, B., Yue, J., Yu, M., Liu, Y., Zhou, M., Lu, D., \& Zhang, J. (2020). Navigating the Pandemic Response Life Cycle: Molecular Diagnostics and Immunoassays in the Context of COVID-19 Management. IEEE Reviews in Biomedical Engineering, 14(30), 1-19. https://doi.org/10.1109/RBME.2020.2991444

Hadi, F. K. (2020). Aktivitas Olahraga Bersepeda Masyarakat Di Kabupaten Malang Pada Masa Pandemi Covid-19. Sport Science and Education Journal, 1(2), 28-36.

Ika. (2020). Pakar UGM Jelaskan Cara Aman Bersepeda di Tengah Pandemi Corona. Universitas Gadjah Mada. $\quad$ https://ugm.ac.id/id/berita/19632-pakar-ugm-jelaskan-cara-aman-bersepeda-di-tengahpandemi-corona

Institute for Transportation and Development Policy. (2020). During Coronavirus, Jakarta's Cycling Grows as does Police Backlash. Itdp.Org. https://www.itdp.org/2020/07/10/during-coronavirus-cycling-grows-asdoes-police-backlash/

Johns Hopkins University CSSE. (2020). COVID-19 Global Cases (Johns Hopkins University CSSE). https://www.iafc.org/topics-and-tools/resources/resource/coronavirus-covid-19-global-cases-(johnshopkins-university-csse)

Kemenkes RI. (2020). Pedoman Pencegahan dan Pengendalian Coronavirus Disease (COVID-19). Germas, $0-115$.

Kementerian Kesehatan RI. (2017). Analisis Lansia Indonesia. Kementerian Kesehatan RI.

Kementerian Kesehatan RI Badan Penelitian dan Pengembangan. (2018). Hasil Utama Riset Kesehatan Dasar 2018. Kementrian Kesehatan Republik Indonesia, 1-100. https://doi.org/1 Desember 2013

Kurniawan, I. \& Sulaiman. 2019. Hubungan Olahraga, Stress, dan Pola Makan Dengan Tingkat Hipertensi di Posyandu Lansia di Kelurahan Sudirejo I Kecamatan Medan Kota. JPSH, 1 (1).

Lara, A.G. \& Hidajah, A.C. 2016. Hubungan Pendidikan, Kebiasaan Olahraga, dan Pola Makan dengan Kualitas Hidup Lansia di Puskesmas Wonokromo, Surabaya. Jurnal Promosi Kesehatan, 4 (1), 59-69.

Mueller, A. L., Mcnamara, M. S., \& Sinclair, D. A. (2020). Why does COVID-19 disproportionately affect older people? Aging, 12(10), 9959-9981.

Papadopoulos, V., Li, L., \& Samplaski, M. (2021). Why does COVID-19 kill more elderly men than women? Is there a role for testosterone? Andrology, 9(1), 65-72. https://doi.org/10.1111/andr.12868

Pribadi, A. 2015. Pelatihan Aerobik untuk Kebugaran Paru dan Jantung bagi Lansia. Jurnal Olahraga Prestasi, 11 (2).

Pusat Data dan Informasi, K. K. R. (2016). Elderly Condition in Indonesia. In Pusdatin Kemenkes.

Rydyznski Moderbacher, C., Ramirez, S. I., Dan, J. M., Grifoni, A., Hastie, K. M., Weiskopf, D., Belanger, S., Abbott, R. K., Kim, C., Choi, J., Kato, Y., Crotty, E. G., Kim, C., Rawlings, S. A., Mateus, J., Tse, L. P. V., Frazier, A., Baric, R., Peters, B., ... Crotty, S. (2020). Antigen-Specific Adaptive Immunity to SARSCoV-2 in Acute COVID-19 and Associations with Age and Disease Severity. Cell, 183(4), 996-1012.e19. https://doi.org/10.1016/j.cell.2020.09.038

S, S. (2017). Exercise and Immune System. International Journal of Physical Education, Sports and Health, 4(1), 200-202. https://doi.org/10.7600/jspfsm1949.41.139

Santoso, D. (2020). Mengantisipasi Wabah Virus Corona Wuhan. Fakultas Kedokteran Universitas Airlangga. https://mediaindonesia.com/opini/286107/mengantisipasi-wabah-virus-corona-wuhan

Satgas Covid-19. (2021). Peta Sebaran Covid-19. https://covid19.go.id/peta-sebaran-covid19 
Sauliyusta, M. \& Rekawati, E. 2016. Aktivitas Fisik Mempengaruhi Fungsi Kognitif Lansia. Jurnal Keperawatan Indonesia, 19 (2), 70-77.

Setijowarno, D., \& Yulianti, A. (2020). Menata Transportasi Bersepeda Di Indonesia. Bisnisnews.ld. https://bisnisnews.id/detail/berita/menata-transportasi-bersepeda-di-indonesia-

Shereen, M. A., Khan, S., Kazmi, A., Bashir, N., \& Siddique, R. (2020). COVID-19 infection: Origin, transmission, and characteristics of human coronaviruses. Journal of Advanced Research, 24, 91-98. https://doi.org/10.1016/j.jare.2020.03.005

Sudibjo, P. dkk. 2014. Gambaran Tekanan Darah Anggota Kelompok Senam Lansia Kecamatan Condong Catur Sleman DIY. Laporan Penelitian. Fakultas IImu Keolahragaan Universitas Negeri Yogyakarta.

Suni, N. S. P. (2020). Kesiapsiagaan Indonesia Menghadapi Potensi Penyebaran Corona. Pusat Penelitian Badan Keahlian DPR RI, XII(3), 14-18. https://berkas.dpr.go.id/puslit/files/info_singkat/Info Singkat-XII3-I-P3DI-Februari-2020-1957.pdf

The University of Texas at Austin. (2020). Coronavirus Spreads Quickly and Sometimes Before People Have Symptoms, Study Finds. https://news.utexas.edu/2020/03/16/coronavirus-spreads-quickly-andsometimes-before-people-have-symptoms-study-finds/

Verdiana, B. M. T. (2020). Update COVID-19 Dunia 31 Desember 2020 Tembus 83 Juta, Kasus Tertinggi Asia di India. https://www.liputan6.com/global/read/4446063/update-covid-19-dunia-31-desember-2020tembus-83-juta-kasus-tertinggi-asia-di-india

WHO. (2013). World health statistics 2013. WHO Press.

Wilk, A. J., Rustagi, A., Zhao, N. Q., Roque, J., Martínez-Colón, G. J., McKechnie, J. L., Ivison, G. T., Ranganath, T., Vergara, R., Hollis, T., Simpson, L. J., Grant, P., Subramanian, A., Rogers, A. J., \& Blish, C. A. (2020). A single-cell atlas of the peripheral immune response in patients with severe COVID-19. Nature Medicine, 26(7), 1070-1076. https://doi.org/10.1038/s41591-020-0944-y

worldmeters. (2020). COVID-19 CORONAVIRUS PANDEMIC. https://www.worldometers.info/coronavirus/

Xavier, E.A.D.C., dkk. 2017. Relationship between Physical Activity and Blood Pressure in the Elderly at the Elderly Posyandu, Banjarejo Village, Ngantang District, Malang Regency. Nursing News Journal, 2 (3).

Yousfi, N., Bragazzi, N. L., Briki, W., Zmijewski, P., \& Chamari, K. (2020). The COVID-19 pandemic: How to maintain a healthy immune system during the lockdown - A multidisciplinary approach with special focus on athletes. Biology of Sport, 37(3), 211-216. https://doi.org/10.5114/biolsport.2020.95125

Yurianto, A. (2020). Pedoman Pencegahan dan Pengendalian Coronavirus Disease (COVID-19). In Direktorat Jendral Pencegahan dan Pengendalian Penyakit.

Zhou, P., Yang, X.-L., Wang, X.-G., Hu, B., Zhang, L., Zhang, W., Si, H.-R., Zhu, Y., Li, B., Huang, C.-L. (2020). Discovery of a Novel Coronavirus Associated With the Recent Pneumonia Outbreak in Humans and Its Potential Bat Origin. BioRxiv. 